\title{
Post-fire response of Araucaria araucana (Molina) K. Koch: Assessment of vegetative resprouting, seed production and germination
}

\section{Respuesta post-fuego de Araucaria araucana (Molina) K. Koch: Evaluación del rebrote vegetativo, producción de semillas y germinación}

\author{
Andrés Fuentes-Ramírez ${ }^{1,2,3 *}$, Paola Arroyo-Vargas ${ }^{1}$, Andrea Del Fierro ${ }^{1} \&$ Franco Pérez ${ }^{1}$ \\ ${ }^{1}$ Laboratorio de Biometría, Departamento de Ciencias Forestales, Universidad de La Frontera, Casilla 54-D, Temuco, Chile. \\ ${ }^{2}$ Centro Butamallín - Investigación en Cambio Global, Universidad de La Frontera, Casilla 54-D, Temuco, Chile. \\ ${ }^{3}$ Instituto de Ecología y Biodiversidad (IEB), Santiago, Chile. \\ *andres.fuentes@ufrontera.cl
}

\begin{abstract}
RESUMEN
Se evaluó la respuesta inicial post-fuego de Araucaria araucana en la Reserva Nacional China Muerta, (centro-sur de Chile $38^{\circ} \mathrm{S}, 71^{\circ} \mathrm{W}$ ) después de un incendio ocurrido en marzo de 2015. Se reporta una alta capacidad de rebrote vegetativo desde las raíces y también de la copa, siendo estos últimos brotes los más numerosos en el tiempo. La producción de semillas, viabilidad y germinación también fue alta (>60\%), sugiriendo una buena recuperación de $A$. araucana, especialmente en el primer año después del fuego.
\end{abstract}

Araucaria araucana (Molina) K. Koch is an endemic, endangered and long-lived native conifer from Chile and Argentina. Forests formed by $A$. araucana are particularly valuable because of their significant biodiversity and cultural values (Aagesen 1998). Fire disturbance is a key factor influencing the dynamic of Araucaria araucana forests in the Andean region of southern South America (Gonzalez et al. 2005, Mundo et al. 2013). Despite the importance of fire in shaping the structure and composition of $A$. araucana forests, the increase in the occurrence and severity of wildfires caused by human activities can compromise the conservation of this emblematic species (Gonzalez \& Veblen 2006, Kitzberger et al. 1997). Although A. araucana is adapted to withstand fires of low-to-moderate severity due to its thick bark (Burns 1993), it has been argued that the difficulty for germination and seedling recruitment in the field due to low seed production, granivory by rodents and increased seed harvesting for trading, could compromise its capacity of regeneration (Sanguinetti \& Kitzberger 2009). Nevertheless, there is still little knowledge regarding its reproduction success after fire, including vegetative resprouting and germination. In this research we aimed at (1) assessing the potential differences in frequency and abundance of vegetative resprouting from belowground and canopy buds of burned araucarias, (2) estimating the production and dispersion range of seeds from burned individuals, and (3) evaluating the viability and germination of seeds and the initial growth of araucaria seedlings after fire. Disentangling these initial responses can shed light on the surviving strategies of $A$. araucana to cope with the increased frequency of fire predicted for south-central Chile (McWethy et al. 2018). By using a large-scale wildfire that burned the National Reserve China Muerta (southcentral Chile; $38^{\circ} \mathrm{S}, 71^{\circ} \mathrm{W}$ ) in March of 2015, we assessed seed production and germination, seedling growth and the resprouting capacity of fire-affected araucaria individuals.

Within a burned patch of ca. 7 ha, we randomly chose a total of 90 burned individuals of $A$. araucana (ranging from 0.5 to $12 \mathrm{~m}$ in height), and assessed the vegetative reproduction from resprouting buds. Green buds coming up from the canopy were counted in 30 trees (Fig. 1a). Green buds found at the base of the trunk (from belowground) were also counted in another 30 individuals (Fig. 1b). We also recorded another 30 individuals that did not present any type of resprouting after fire. All the trees were gps-marked to allow its assessment the first (2016), the second (2017) and the third (2018) year after fire (in April). Thus, each individual exhibiting canopy, belowground or no buds was followed over time to assess the number of buds found in each year of the study. A mixed model was fit, with type of sprouting (i.e., canopy and root buds) and year of sampling as fixed factors and trees as random term. Post-hoc Tukey tests (with $\alpha=0.05$ ) were carried out to compare the mean number of canopy and belowground buds for each year of the study.

In the same area and at the same time (in April 2016), 
we chose another 14 reproductive female individuals that were partially burned in the 2015 fire (with $70 \%$ of the crown damaged, approximately), and counted the number of mature cones per tree. Additionally, we used a $1 \mathrm{~m}^{2}$ square plot established along a distance gradient from the base of each tree to assess the dispersion of seeds produced one year after fire. The sampling started right next to the trunk (at zero $\mathrm{m}$ ), and extended up to $15 \mathrm{~m}$ away from the tree, where no more seed were found (i.e., the maximum dispersal distance). We then defined four distance classes by pulling together the plots at distances $0-3,4-7,8-11$ and 12-15 m. This procedure was repeated for each cardinal direction from the focal tree (i.e., N, S, E and W), totaling 224 sampling units. A mixed model was fit, with distance class as fixed factor and trees as random term. Post-hoc Tukey tests (with $\alpha=0.05$ ) were carried out to compare the

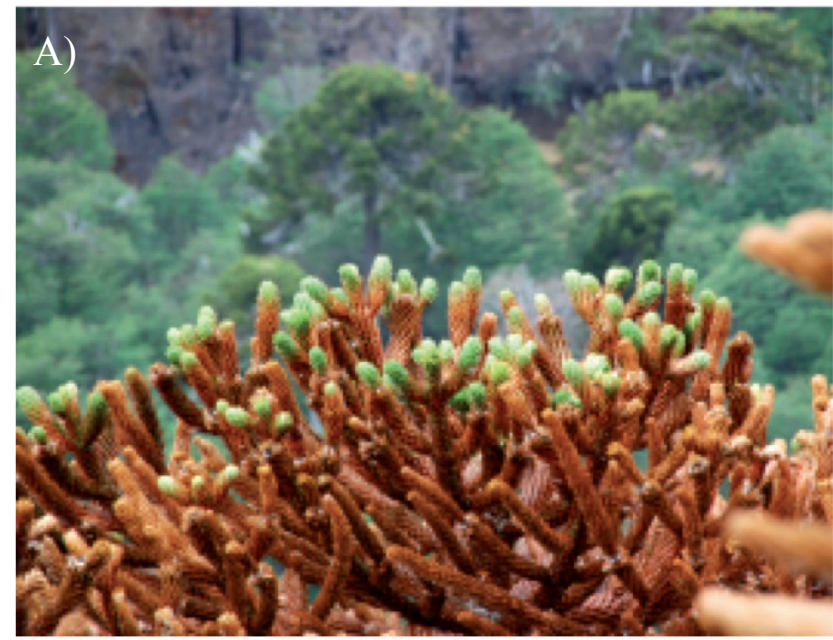

mean number of seeds along the distance-class gradient. All the counted seeds were collected in April 2016 and stored at $3{ }^{\circ} \mathrm{C}$ for four months in the lab. We then assessed the seed viability by examining the seed's embryo and by using the float test (Schatral \& Fox 1994). Then, in late August of 2016, we individually-sowed 300 seeds in containers filled with field-collected soil, and assessed the germination in the greenhouse for six months using Kaplan-Meier curves. Immediately upon seedling emergence, we started to measure the height of each individual weekly to assess the growth (in $\mathrm{cm}$ ) for another six months until July 2017. All the above-mentioned statistical analyses were performed in R using the lme 4 and emmeans packages for fitting the mixed models, and the survival package for estimating the germination curve (R Core Team 2018).

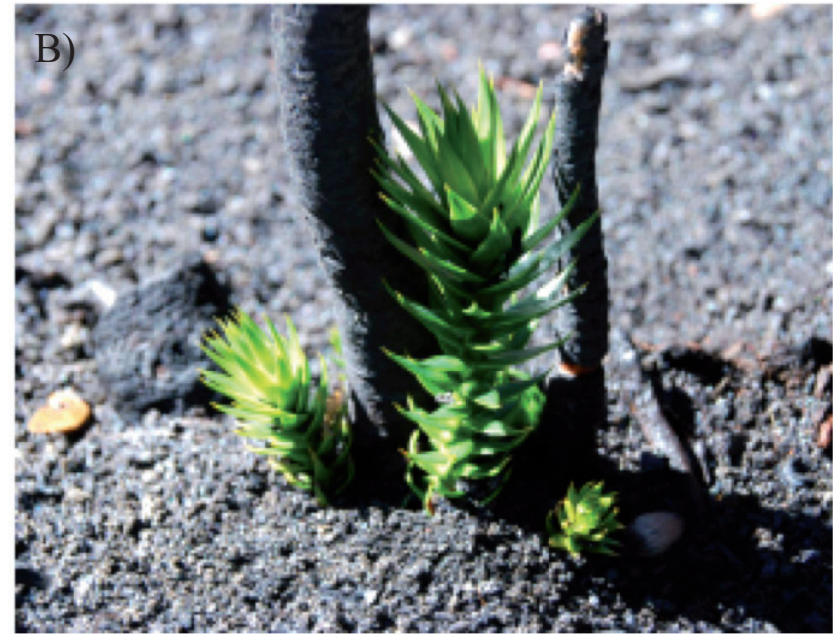

Figure 1. Pictures of fire-affected araucarias with a) canopy and b) belowground buds that were considered in the study in the National Reserve China Muerta, south-central Chile $\left(38^{\circ} \mathrm{S}, 71^{\circ} \mathrm{W}\right)$. / Imágenes de araucarias quemadas con brotes en a) copa y b) raíz considerados en el estudio en la Reserva Nacional China Muerta, centro-sur de Chile $\left(38^{\circ} \mathrm{S}, 71^{\circ} \mathrm{W}\right)$.
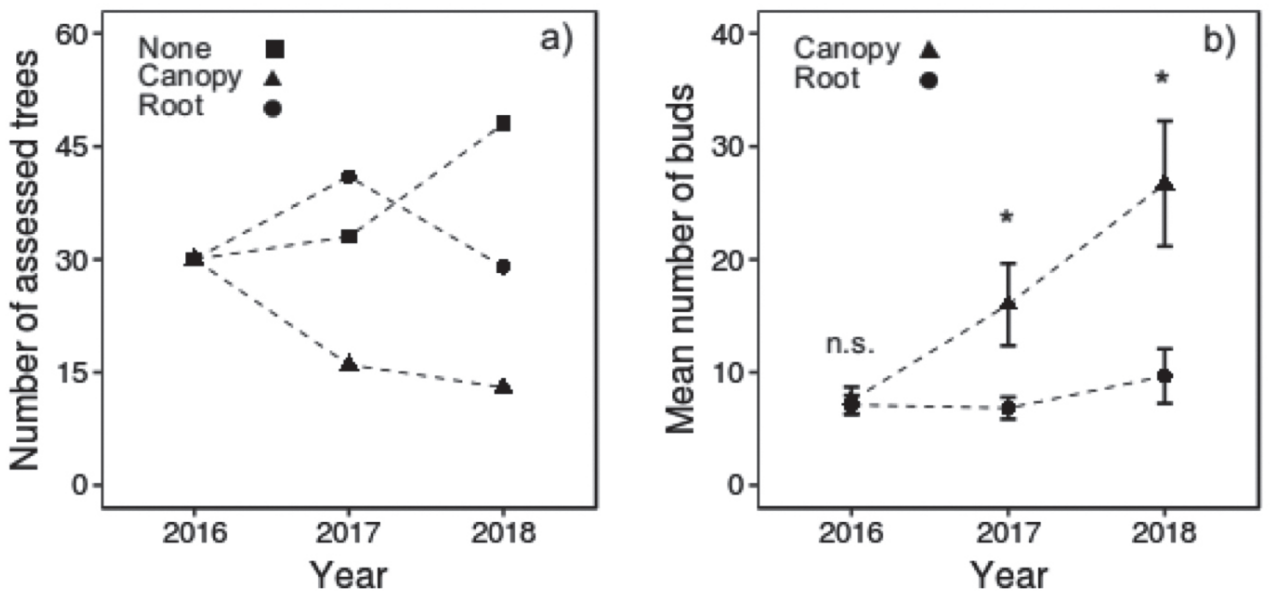

FiguRE 2. a) Number of assessed A. araucana individuals presenting belowground, canopy or none sprouting buds, and b) mean number of buds $( \pm$ SE) from belowground and in the canopy, one (2016), two (2017) and three (2018) years after fire. * denotes p<0.05 using Tukey tests; n.s.=not significant. / a) Número de individuos de $A$. araucana evaluados que presentaban brotes de raíz, de copa o ningún tipo de brote, y b) número medio de brotes ( $\pm \mathrm{EE}$ ) contados en la raíz y en copa a uno (2016), dos (2017) y tres (2018) años después del fuego. * representa $\mathrm{p}<0.05$ usando prueba de Tukey; n.s. $=$ no significativo. 
Our results showed that the number of A. araucana individuals with canopy buds decreased over time, from 30 in 2016 to 13 in 2018 (Fig. 2a). On the other hand, trees with belowground buds increased in the second year (from 30 to 41), but decreased to 29 individuals in 2018 (similar to what was recorded in the first year). Individuals with no resprouts in 2016 increased over time, accounting for 33 in 2017 and 48 in 2018 (Fig. 2a). This was mainly due to the abrupt decrease in the number of trees that changed from canopy buds in 2016 to no sprouts in the following years, which was notorious in the field and is presumably attributable to desiccation of trees (i.e., ephemeral resprouts; A. Fuentes-Ramírez, pers. comm.). Interestingly, we did not find individuals presenting both types of resprouting (i.e., trees with canopy and belowground buds at the same time).

When looking at the number of buds per tree, Araucaria araucana showed a high capacity for vegetative resprouting after fire, especially from the canopy foliage (Fig. 2b). One year after fire, the mean number of buds in the canopy and belowground were similar (7.5 vs. 5.9, respectively; Tukey test, $\mathrm{p}=0.967$ ). Two years after fire, the mean number of buds in the canopy was more than two times larger than the number of buds from belowground (16 vs. 7, respectively; Tukey test, $\mathrm{p}=0.006$ ), and in the third year, the difference between canopy and belowground buds continued to be even larger (26 vs. 9 , respectively; Tukey test, $\mathrm{p} \leq 0.001$ ). Despite the decrease in the number of $A$. araucana trees with canopy buds over time ( $<<0.001)$, the individuals that persisted produced a significantly higher number of buds than the trees with belowground resprouting $(\mathrm{p}<0.001$; Fig. $2 \mathrm{~b}$ ). These results revealed that both resprouting strategies are important for $A$. araucana to survive fire. In fact, we observed that canopy buds were more abundant in larger and less fire-affected trees, and belowground buds were more frequent in smaller and more fire-affected individuals (A. Fuentes-Ramírez, pers. comm.). Nevertheless, further monitoring is needed to confirm whether these post-fire resprouting strategies persist over time or they are just an ephemeral response.

One year after fire (in 2016), each of the sampled female tree produced 10 matured cones on average (range: 4-18), which yielded a mean of 172 seeds per tree (range: 29-453). However, seed production in the following years (2017 and 2018) was virtually zero. This response could be related to the seed production cycle in $A$. araucana, which takes two years to produce fully matured cones. We observed at the beginning of the study that several araucarias that survived the fire already had mature cones from the previous year, and seeds from these cones were dispersed during the first year after fire (2016). Furthermore seed dispersion occurred in the close vicinity of trees, at 0-3 meters away from the trunk, but it significantly decreased with further distances away from the trunk $\left(\mathrm{F}_{3,250}=29.52, \mathrm{p}<0.001 ;\right.$ Fig. 3a $)$. At the hectare scale, seed production of burned $A$. araucana individuals reached a
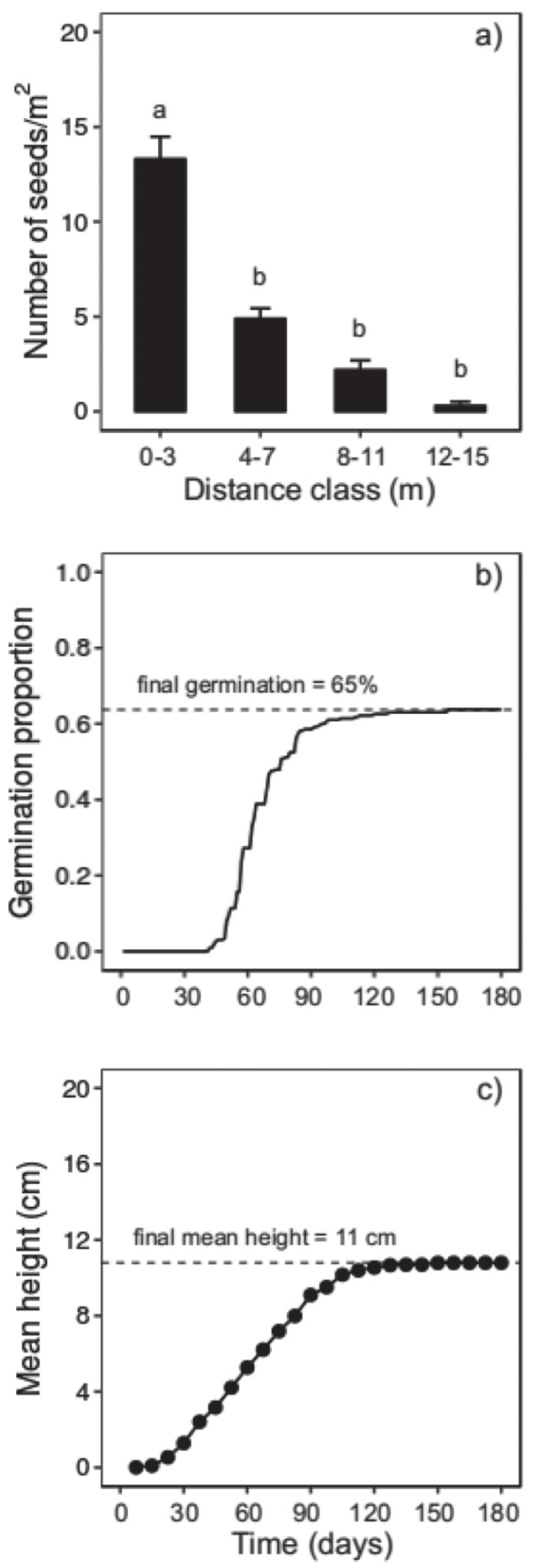

FIgURE 3. a) Mean number of $A$. araucana seeds (+SE) per $\mathrm{m}^{2}$ along a distance gradient from the base of the tree trunk. b) Germination curve of $A$. araucana seeds in a greenhouse trial for six months. c) Height increment of A. araucana seedlings evaluated in a period of six months after germination. Different letters above bars in a) indicate statistically significant differences at $\alpha=0.05$ for the means using Tukey test. / a) Número medio de semillas de $A$. araucana ( $+\mathrm{EE}$ ) por $\mathrm{m}^{2}$ en un gradiente de distancia desde la base del tronco. b) Curva de germinación $A$. araucana en invernadero en un periodo de seis meses. c) Crecimiento en altura de plántulas de $A$. araucana evaluado en un periodo de seis meses post-germinación. Distintas letras sobre las barras en a) indican diferencias estadísticamente significativas con $\alpha=0,05$ para las medias utilizando la prueba de Tukey. 
mean of 133,000 seeds/ha within 0-3 m away, 49,000 seeds/ ha within 4-7 $\mathrm{m}$ away, 22,000 seeds/ha within 8-11 m away and 3,000 seeds/ha within $12-15 \mathrm{~m}$ away from the trunk. These numbers are lower than those reported by Sanguinetti (2014) in Lanín National Park (Argentina), which can be explained not only by the reduced number of trees assessed in our study, but also because of the damage of fire itself that burned ca. $70 \%$ of the crown. However, Donoso et al. (2014) reports a similar production of seeds per hectare for nearby A. araucana forests in Lonquimay (La Araucanía, Chile). Thus, our results provide reliable information regarding seed production of burned A. araucana forests, which is even comparable to unburned forests within the same region and may suggest the recovery of araucaria after fire.

The viability of the seeds produced one year after fire was $70 \%$. In the greenhouse, $A$. araucana seeds started to germinate at the $40^{\text {th }}$ day, with a rapid rate of germination until day $90^{\text {th }}$. Then, the germination slowed down to finally stabilize at ca. $65 \%$ by day $150^{\text {th }}$, which represents 195 emerged seedlings (Fig. 3b). Similar results have been shown in a range of different experiments (Duplancic 2011, Duplancic et al. 2015), emphasizing the key role of synchronized masting for increased germination and seedling establishment (Sanguinetti \& Kitzberger 2008). In terms of growth, araucaria seedlings grew consistently after germination for four months (Feb-May), reaching a mean height of $11 \mathrm{~cm}$ at the end of the trial $(\min =3.5$ and $\max =17.5 \mathrm{~cm}$ at the sixth month; Fig. 3c). No seedling mortality occurred during the growth period.

Overall, this research contributes to expanding our knowledge regarding the survival and reproduction strategies of $A$. araucana forests affected by fire. A rapid initial sprouting capacity is reported for burned trees from both canopy and belowground buds, and a high germination and growth rates were observed in the greenhouse. Thus, when seed production and seedling establishment are limited in the field (due to the synchrony of masting events, poor germination rate and/or by seed granivory; Sanguinetti \& Kitzberger 2009), vegetative reproduction via canopy and belowground buds is the most common strategy of $A$. araucana to survive fire. Additionally, our study showed that using assisted techniques in the greenhouse can help to yield better germination rates and seedling growth, both crucial processes for the recovery of $A$. araucana forests through restoration plans (i.e., planting).

\section{ACKNOWLEDGEMENTS}

Funding provided by FONDECYT $\mathrm{N}^{\circ} 11150487$. AFR is supported by Concurso Nacional Inserción en la Academia 2017 CONICYT-PAI 79170054. We thank to Soraya
Calzadilla and Oscar Barra for their assistance in the laboratory and greenhouse work. Two reviewers made a number of suggestions greatly improving the paper.

\section{REFERENCES}

AAgESEN, D.L. 1998. Indigenous resource rights and conservation of the Monkey-Puzzle tree (Araucaria araucana, Araucariaceae): A case study from southern Chile. Economic Botany 52: 146-160.

Burns, B.R. 1993. Fire-induced dynamics of Araucaria araucanaNothofagus antarctica forest in the southern Andes. Journal of Biogeography 20: 669-685.

Donoso, S.R., Pena-Rojas, K., Espinoza, C., Galdames, E., Pacheco, C. 2014. Production, permanence and germination of seeds of Araucaria araucana (Mol.) K. Koch in natural forests, used by indigenous communities in southern Chile. Interciencia 39: 338-343.

Duplancic, M. 2011. Germinación de semillas de Araucaria araucana provenientes del bosque xérico Nor-Patagónico. Multequina: Latin American Journal of Natural Resources 20: 113-115.

Duplancic, M., Martinez, E., Cavagnaro, B., Herrera, M., Navas, A.L. 2015. Factors affecting germination of Araucaria araucana (Araucariaceae) seeds from the xeric forest. Revista de la Facultad de Ciencias Agrarias 47: 71-82.

Gonzalez, M.E., Veblen, T.T. 2006. Climatic influences on fire in Araucaria araucana-Nothofagus forests in the Andean cordillera of south-central Chile. Ecoscience 13: 342-350.

Gonzalez, M.E., Veblen, T.T., Sibold, J.S. 2005. Fire history of Araucaria-Nothofagus forests in Villarrica National Park, Chile. Journal of Biogeography 32: 1187-1202.

Kitzberger, T., Veblen, T.T., Villalba, R. 1997. Climatic influences on fire regimes along a rain forest to xeric woodland gradient in northern Patagonia, Argentina. Journal of Biogeography 24: 35-47.

McWethy, D.B., Pauchard, A., Garcia, R.A., Holz, A., Gonzalez, M.E., Veblen, T.T., Stahl, J., Currey, B. 2018. Landscape drivers of recent fire activity (2001- 2017) in south-central Chile. Plos ONE 13(8): e0201195.

Mundo, I.A., Kitzberger, T., Roig Junent, F.A., Villalba, R., Barrera, M.D. 2013. Fire history in the Araucaria araucana forests of Argentina: human and climate influences. International Journal of Wildland Fire 22: 194-206.

R Core TEAm. 2018. R: A language and environment for statistical computing. R Foundation for Statistical Computing, Vienna, Austria. URL: https://www.R-project.org/.

Sanguinetti, J. 2014. Producción de semillas de Araucaria araucana (Mol.) K. Koch durante 15 años en diferentes poblaciones del Parque Nacional Lanín (NeuquénArgentina). Ecología Austral 24: 265-275.

Sanguinetti, J., KitzBerger, T. 2008. Patterns and mechanisms of masting in the large-seeded southern hemisphere conifer Araucaria araucana. Austral Ecology 33: 78-87.

SAnguinetTi, J., KitzBerger, T. 2009. Araucaria araucana temporal and spatial seedling establishment patterns: masting, seed predation and understory vegetation effects. Revista Chilena de Historia Natural 82: 319-335.

Schatral, A., Fox, J. 1994. Quality and viability of seeds in the genus Hibbertia. Seed Science and Technology 22: 273284.

Recibido: 25.07 .2018

Aceptado: 28.01.2019 